\title{
Transient Accumulation of Jasmonic Acid During the Synchronized Hypersensitive Cell Death in Tobacco mosaic virus-Infected Tobacco Leaves
}

\author{
Shigemi Seo, ${ }^{1,4}$ Hideharu Seto, ${ }^{2}$ Hiromoto Yamakawa, ${ }^{3,4}$ and Yuko Ohashi ${ }^{1,4}$ \\ ${ }^{1}$ Department of Molecular Genetics, National Institute of Agrobiological Resources, Tsukuba, Ibaraki \\ 305-8602, Japan; ' Institute of Physical and Chemical Research (RIKEN), Wako, Saitama 351-0198, \\ Japan; ${ }^{3}$ Institute of Biological Sciences, University of Tsukuba, Tsukuba, Ibaraki 305-8572, Japan; ${ }^{4}$ Core \\ Research for Evolutional Science and Technology (CREST), Chiyoda-ku, Tokyo 101-0062, Japan \\ Accepted 24 October 2000.
}

Jasmonic acid (JA) transiently accumulated during temperature-dependent synchronous necrotic lesion formation in Tobacco mosaic virus-infected tobacco leaves. The accumulation of JA was preceded by activation of a tobacco mitogen-activated protein kinase, WIPK, which functions upstream of $\mathrm{JA}$ in wound signal transduction pathways.

The hypersensitive reaction (HR) is a plant defense system against pathogen attack. HR is characterized by the rapid death of infected cells accompanying the formation of necrotic lesions in which pathogens are thought to be enclosed. Events slightly preceding the appearance of lesions are an increase in the endogenous levels of salicylic acid (SA) (Malamy et al. 1992; Yalpani et al. 1991) and ethylene (De Laat and Van Loon 1983) and the subsequent accumulation of transcripts for pathogenesis-related (PR) proteins (Guo et al. 2000; Malamy et al. 1992). Because exogenously supplied SA and ethylene induce accumulation of transcripts for PR proteins (Brederode et al. 1991; Eyal et al. 1992; Linthorst et al. 1990; Memelink et al. 1990), SA and ethylene are thought to be endogenous signals in the PR gene expression during HR (Dong 1998; Yang et al. 1997).

Jasmonic acid is a signal molecule in wound responses of plants (Creelman and Mullet 1995; Wasternack and Parthier 1997). Exogenously supplied JA induces the expression of genes encoding basic PR proteins at the transcript and protein levels (Niki et al. 1998; Schweizer et al. 1997; Xu et al. 1994), suggesting that JA is a candidate for inducers of this type of PR protein. Little has been published, however, on changes in endogenous JA levels during HR. In Alternaria brassicicolainoculated leaves of Arabidopsis thaliana plants, endogenous levels of JA began to increase coincident with an accumulation of the transcript of JA-inducible plant defensin gene (Penninckx et al. 1996). Kenton et al. (1999) used Pseudomonas syringae pv. phaseolicola-infected tobacco leaves to

Corresponding author: Y. Ohashi; Telephone: +81 29838 7440; Fax: +81 29838 7044; E-mail: yohashi@ss.abr.affrc.go.jp determine that JA accumulated 3-h postinoculation, paralleling the occurrence of enhanced electrolyte leakage, which is an HR-related event.

In the HR-inducing systems described above, fungal and bacterial pathogens gradually move from infected cells to uninfected cells, resulting in the asynchronous induction of HR. To study the profiles of JA induction during HR, we used a synchronous HR-inducing system. The HR of tobacco to Tobacco mosaic virus (TMV) occurs in cultivars carrying the $N$ gene ( $N N$ tobacco) but not in cultivars lacking this gene ( $n n$ tobacco) (Holmes 1938). The $N$ gene-mediated HR is induced at temperatures below $25^{\circ} \mathrm{C}$ but not above $28^{\circ} \mathrm{C}$ (Kassanis 1952; Weststeijn 1981). When TMV-infected $N N$ tobacco leaves are incubated at temperatures above $28^{\circ} \mathrm{C}$ and transferred to temperatures below $25^{\circ} \mathrm{C}$, HR is induced synchronously in the infected tissue (Weststeijn 1981).

To synchronously induce HR, TMV-inoculated leaves of Samsun NN, an $N N$ tobacco cultivar, were incubated at $30^{\circ} \mathrm{C}$ for $40 \mathrm{~h}$, and then at $20^{\circ} \mathrm{C}$. In the infected leaves, the endogenous level of JA began to increase $5 \mathrm{~h}$ after the temperature shift, reaching a maximum at $9 \mathrm{~h}$, and gradually declined to the basal level by $36 \mathrm{~h}$ (Fig. 1). We found that with the use of this synchronous system, enhanced electrolyte leakage is detectable $8 \mathrm{~h}$ after the temperature shift and simultaneously with the appearance of necrotic lesions (Ohashi and Shimomura 1976; Ohtsubo et al. 1999) (Fig. 1). Thus, the accumulation of JA preceded the appearance of necrotic lesions. No significant increase in endogenous JA levels was seen in TMV-inoculated leaves of Samsun nn, an $n n$ tobacco cultivar, and in mock-inoculated leaves of both cultivars, suggesting that neither TMV-infection nor the temperature shift causes JA accumulation.

A possible role of JA accumulation during HR is to induce expression of genes encoding basic PR proteins. We observed that transcripts of the JA-inducible basic PR-1 gene started to accumulate $6 \mathrm{~h}$ after TMV-inoculated Samsun NN leaves were shifted from 30 to $20^{\circ} \mathrm{C}$ (Fig. 2A). This accumulation was $1 \mathrm{~h}$ later than the accumulation of JA (Fig. 1), suggesting that the accumulation of JA precedes the accumulation of transcripts of the basic PR-1 gene. 
Mitogen-activated protein (MAP) kinases are signal molecules that play a central role in the transduction of diverse extracellular stimuli. Plant MAP kinases also have been implicated in defense responses against pathogen attack (Hirt 1997; Zhang and Klessig 1999). Our recent study showed that activation of a MAP kinase, WIPK, is required for JA accumulation in wounded tobacco plants (Seo et al. 1999). To examine activation of WIPK in our synchronous system, a time-course analysis was made of the level of WIPK activity after the temperature shift. Crude leaf extracts were immunoprecipitated with an anti-WIPK antibody (Seo et al. 1999), and the immune complexes were subjected to the kinase assay with myelin basic protein (MBP) as an artificial substrate. In TMV-inoculated, but not mockinoculated Samsun NN leaves, a change in the kinase activity of WIPK was detectable $4 \mathrm{~h}$ after the temperature shift, reaching a peak at $8 \mathrm{~h}$ and declining gradually thereafter (Fig. 2B). The timing of the initial increase in kinase activity was $1 \mathrm{~h}$ earlier than the initial increase in the endogenous
JA levels. There was no MBP kinase activity of WIPK in TMV- or mock-inoculated Samsun nn leaves (data not shown). Consistent with our observation, WIPK is activated $4 \mathrm{~h}$ after the temperature shift from 32 to $22^{\circ} \mathrm{C}$ for TMVinfected leaves of Xanthi nc, an $N N$ tobacco cultivar (Zhang and Klessig 1998). These time-course analyses indicate that during the $N$ gene-mediated HR, the activation of WIPK precedes the accumulation of JA. This is supported by the observation that JA treatment did not activate WIPK (Kumar and Klessig 2000).

The idea of cross talk between defense responses to pathogen attack and wounding has been discussed previously (Doares et al. 1995; Felton et al. 1998; Sano et al. 1994). On the basis of this concept, it was suggested that the JAsignaling pathway in HR occurs very early in the plant resistance response to pathogens and may have features in common with wound responses. It is therefore possible that the accumulation of JA during HR in TMV-infected tobacco is caused by activation of WIPK.

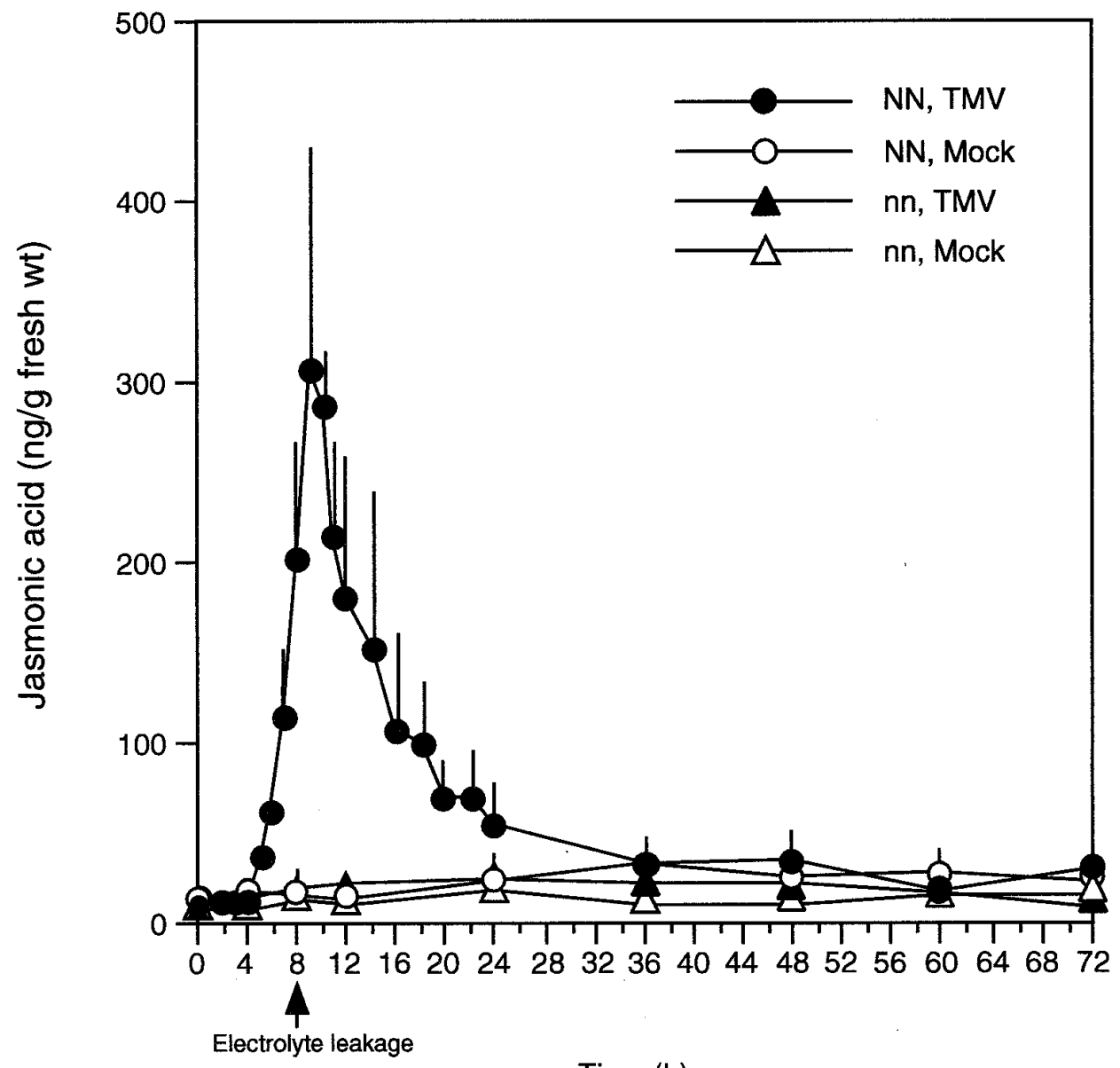

Time (h)

Fig. 1. Levels of jasmonic acid (JA) in Tobacco mosaic virus (TMV)- and mock-inoculated tobacco leaves after temperature shift. Upper, fully expanded healthy leaves of 2-month-old Samsun NN (NN) and Samsun nn (nn) tobacco plants were detached, inoculated with $10 \mu \mathrm{g}$ of TMV per ml or buffer only (Mock), incubated at $30^{\circ} \mathrm{C}$ for $40 \mathrm{~h}$, and shifted to $20^{\circ} \mathrm{C}$ at time 0 . All of the inoculated leaves were set on wet filter paper in transparent boxes and incubated under continuous illumination at an intensity of $120 \mu \mathrm{E} \cdot \mathrm{m}^{-2} \cdot \mathrm{s}^{-1}$. Leaves were harvested at the indicated time after the temperature shift and used for quantitation of JA, which was extracted as described (Lehmann et al. 1995) and analyzed by gas chromatography-mass spectrometry selected ion monitoring as described (Seo et al. 1999). $\left[{ }^{2} \mathrm{H}_{2}\right]( \pm$ )-JA was used as an internal standard (Nojiri et al. 1992). Values are the mean \pm standard deviation from three independent measurements. All data are corrected for losses. Arrow indicates the earliest time point where electrolyte leakage was observed. 

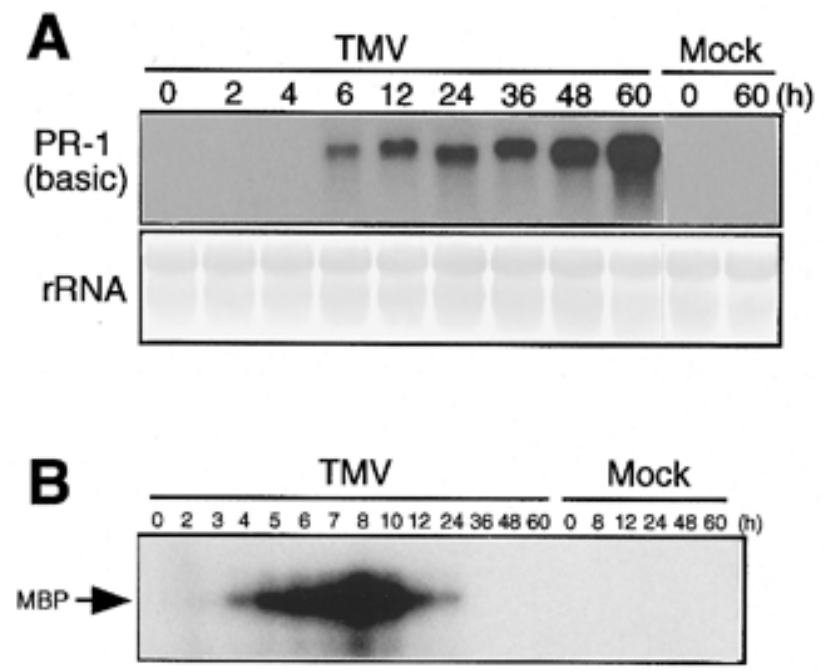

Fig. 2. Levels of basic pathogenesis-related (PR)-1 transcripts and myelin basic protein (MBP) kinase activity of WIPK in Tobacco mosaic virus (TMV)- and mock-inoculated tobacco leaves after the temperature shift. Upper, fully expanded healthy leaves of 2-month-old Samsun NN tobacco plants were detached, inoculated with $10 \mu \mathrm{g}$ of TMV per ml or buffer only (Mock), incubated at $30^{\circ} \mathrm{C}$ for $40 \mathrm{~h}$, and shifted to $20^{\circ} \mathrm{C}$ at time 0 . Leaves were harvested at the indicated time after the temperature shift and used for RNA gel blot analysis or myelin basic protein (MBP) kinase assay of WIPK. A, RNA gel blot analysis. Aliquots of $20 \mu \mathrm{g}$ of total RNA per lane were fractionated by gel electrophoresis, transferred to nylon membranes, and subjected to hybridization with the basic PR-1 cDNA probe (Niki et al. 1998). To standardize RNA loading, the blot was stained with methylene blue (rRNA). B, MBP kinase activity. Soluble proteins containing $50 \mu \mathrm{g}$ of total protein were immunoprecipitated with $5 \mu \mathrm{g}$ of the anti-WIPK antibody, and the level of MBP kinase activity was measured in the immunoprecipitate (Seo et al. 1999). Arrow indicates the position of the phosphorylated MBP. A and B, The experiments were repeated three times with similar results.

\section{ACKNOWLEDGMENTS}

We thank N. Ohtsubo for helpful discussion. This work was supported by the Enhancement of Center of Excellence (COE), Special Coordination Funds for Promoting Science and Technology, the Science and Technology Agency, Japan.

\section{LITERATURE CITED}

Brederode, F. T., Linthorst, H. J. M., and Bol, J. F. 1991. Differential induction of acquired resistance and PR gene expression in tobacco by virus infection, ethephon treatment, UV light and wounding. Plant Mol. Biol. 17:1117-1125.

Creelman, R. A., and Mullet, J. E. 1995. Jasmonic acid distribution and action in plants: Regulation during development and response to biotic and abiotic stress. Proc. Natl. Acad. Sci. USA 92:4114-4119.

De Laat, A. M. M., and Van Loon, L. C. 1983. The relationship between stimulated ethylene production and symptom expression in virusinfected tobacco leaves. Physiol. Plant Pathol. 22:261-273.

Doares, S. H., Narváez-Vásquez, J., Conconi, A., and Ryan, C. A. 1995. Salicylic acid inhibits synthesis of proteinase inhibitors in tomato leaves induced by systemin and jasmonic acid. Plant Physiol. 108:1741-1746.

Dong, X. 1998. SA, JA, ethylene, and disease resistance in plants. Curr. Opin. Plant Biol. 1:316-323.

Eyal, Y., Sagee, O., and Fluhr, R. 1992. Dark-induced accumulation of a basic pathogenesis-related (PR-1) transcript and a light requirement for its induction by ethylene. Plant Mol. Biol. 19:589-599.

Felton, G. W., Korth, K. L., Bi, J. L., Wesley, S. V., Huhman, D. V., Mathews, M. C., Murphy, J. B., Lamb, C., and Dixon, R. A. 1998. Inverse relationship between systemic resistance of plants to microor- ganisms and to insect herbivory. Curr. Biol. 9:317-320.

Guo, A., Salih, G., and Klessig, D. F. 2000. Activation of a diverse set of genes during the tobacco resistance response to TMV is independent of salicylic acid; induction of a subset is also ethylene independent. Plant J. 21:409-418.

Hirt, H. 1997. Multiple roles of MAP kinases in plant signal transduction. Trends Plant Sci. 2:11-15.

Holmes, F. O. 1938. Inheritance of resistance to tobacco-mosaic disease in tobacco. Phytopathology 28:553-561.

Kassanis, B. 1952. Some effects of high temperature on the susceptibility of plants to infection with viruses. Ann. Appl. Biol. 39:358-369.

Kenton, P., Mur, L. A. J., Atzorn, R., Wasternack, C., and Draper, J. 1999. (-)-Jasmonic acid accumulation in tobacco hypersensitive response lesions. Mol. Plant-Microbe Interact. 12:74-78.

Kumar, D., and Klessig, D. F. 2000. Differential induction of tobacco MAP kinases by the defense signals nitric oxide, salicylic acid, ethylene, and jasmonic acid. Mol. Plant-Microbe Interact. 13:347-351.

Lehmann, J., Atzorn, R., Brückner, C., Reinbothe, S., Leopold, J., Wasternack, C., and Parthier, B. 1995. Accumulation of jasmonate, abscisic acid, specific transcripts and proteins in osmotically stressed barley leaf segments. Planta 197:156-162.

Linthorst, H. J. M., Melchers, L. S., Mayer, A., Van Roekel, J. S. C., Cornelissen, B. J. C., and Bol, J. F. 1990. Analysis of gene families encoding acidic and basic $\beta-1,3$-glucanases of tobacco. Proc. Natl. Acad. Sci. USA 87:8756-8760.

Malamy, J., Henning, J., and Klessig, D. F. 1992. Temperaturedependent induction of salicylic acid and its conjugates during the resistance response to tobacco mosaic virus infection. Plant Cell 4:359366.

Memelink, J., Linthorst, H. J. M., Schilperoort, R. A., and Hoge, J. H. C. 1990. Tobacco genes encoding acidic and basic isoforms of pathogenesis-related proteins display different expression patterns. Plant Mol. Biol. 14:119-126.

Niki, T., Mitsuhara, I., Seo, S., Ohtsubo, N., and Ohashi, Y. 1998. Antagonistic effect of salicylic acid and jasmonic acid on the expression of pathogenesis-related (PR) protein genes in wounded mature tobacco leaves. Plant Cell Physiol. 39:500-507.

Nojiri, H., Yamane, H., Seto, H., Yamaguchi, I., Murofushi, N., Yoshihara, T., and Shibaoka, H. 1992. Qualitative and quantitative analysis of endogenous jasmonic acid in bulbing and non-bulbing onion plants. Plant Cell Physiol. 33:1225-1231.

Ohashi, Y., and Shimomura, T. 1976. Leakage of cell constituents associated with local lesion formation on Nicotiana glutinosa leaf infected with tobacco mosaic virus. Ann. Phytopathol. Soc. Jpn. 42:436-441.

Ohtsubo, N., Mitsuhara, I., Koga, M., Seo, S., and Ohashi, Y. 1999. Ethylene promotes the necrotic lesion formation and basic PR gene expression in TMV-infected tobacco. Plant Cell Physiol. 40:808-817.

Penninckx, I. A. M. A., Eggermont, K., Terras, F. R. G., Thomma, B. P. H. J., De Samblanx, G. W., Buchala, A., Métraux, J.-P., Manners, J. M., and Broekaert, W. F. 1996. Pathogen-induced systemic activation of a plant defensin gene in Arabidopsis follows a salicylic acidindependent pathway. Plant Cell 8:2309-2323.

Sano, H., Seo, S., Orudgev, E., Youssefian, S., Ishizuka, K., and Ohashi, Y. 1994. Expression of the gene for a small GTP binding protein in transgenic tobacco elevates endogenous cytokinin levels, abnormally induces salicylic acid in response to wounding, and increases response to tobacco mosaic virus infection. Proc. Natl. Acad. Sci. USA 91:10556-10560.

Schweizer, P., Buchala, A., Silverman, P., Seskar, M., Raskin, I., and Métraux, J.-P. 1997. Jasmonate-inducible genes are activated in rice by pathogen attack without a concomitant increase in endogenous jasmonic acid levels. Plant Physiol. 114:79-88.

Seo, S., Sano, H., and Ohashi, Y. 1999. Jasmonate-based wound signal transduction requires activation of WIPK, a tobacco mitogenactivated protein kinase. Plant Cell 11:289-298.

Wasternack, C., and Parthier, B. 1997. Jasmonate-signalled plant gene expression. Trends Plant Sci. 2:302-307.

Weststeijn, E. A. 1981. Lesion growth and virus localization in leaves of Nicotiana tabacum cv. Xanthi nc after inoculation with tobacco mosaic virus and incubation alternately at $22^{\circ} \mathrm{C}$ and $32^{\circ} \mathrm{C}$. Physiol. Plant Pathol. 18:357-368.

Xu, Y., Chang, P.-F. L., Liu, D., Narasimhan, M. L., Raghothama, K. G., Hasegawa, P. M., and Bressan, R. A. 1994. Plant defense genes are synergistically induced by ethylene and methyl jasmonate. Plant Cell 
6:1077-1085.

Yalpani, N., Silverman, P., Wilson, T. M. A., Kleier, D. A., and Raskin, I. 1991. Salicylic acid is a systemic signal and an inducer of pathogenesis-related proteins in virus-infected tobacco. Plant Cell 3:809818.

Yang, Y., Shah, J., and Klessig, D. F. 1997. Signal perception and transduction in plant defense responses. Genes Dev. 11:1621-1639.
Zhang, S., and Klessig, D. F. 1998. Resistance gene $N$-mediated de novo synthesis and activation of a tobacco mitogen-activated protein kinase by tobacco mosaic virus infection. Proc. Natl. Acad. Sci. USA 95:7433-7438.

Zhang, S., and Klessig, D. F. 1999. Pathogen-induced MAP kinases in tobacco. Pages 65-84 in: MAP Kinases in Plant Signal Transduction, H. Hirt, ed. Springer-Verlag, Heidelberg, Germany. 